\title{
Prevalence of Pediculosis Capitis and Associated Factors among Primary School Children at Kawiley Village North Sulawesi, Indonesia
} Herlina Wungouw ${ }^{1,2^{*}}$, Ventje Memah $^{3}$, Christine Salaki ${ }^{3}$, Dantje Tarore ${ }^{3}$, Ronald Ottay ${ }^{1}$, Vanda D. Doda ${ }^{1}$, Irene Rumampuk $^{4}$, Hizkia Rumampuk ${ }^{4}$

${ }^{1}$ Faculty of Medicine, Sam Ratulangi University, Bahu, Malalayang, Manado City, North Sulawesi, Indonesia

${ }^{2}$ Entomology Study Program, Postgraduate Program, University Sam Ratulangi, Manado, North Sulawesi

${ }^{3}$ Faculty of Agriculture, Sam Ratulangi University, Bahu, Malalayang, Manado City, North Sulawesi, Indonesia

${ }^{4}$ General Practitioner at Kawiley

DOI: $10.36347 /$ sjams.2020.v08i11.008

| Received: 21.10.2020 | Accepted: 05.11.2020 | Published: 11.11.2020

*Corresponding author: Herlina Wungouw

Abstract

The prevalence of pediculosis capitis is still high worldwide regardless of the many attempts to eliminate the cause either in developed or developing countries. Many factors contribute to the difficulties to eradicate this problem, one being the efficiency of the mite to breed and spread undetected. Children, who are affected, are mostly in their primary school period, may experience anemia, sleeping disturbances, wound in the scalp, negative social stigma, and problem in concentration and learning. Mother, as a primary caregiver for children in a conventional or domesticated society, may take part in the development and spread of pediculosis capitis in these children. This study explores the prevalence of pediculosis capitis in a rural area in Indonesia and its association to gender, mothers' level of education. Method: This study is a cross sectional study that depicts and analyze the prevalence of pediculosis capitis and its associated factors at one primary school in Kawiley village North Sulawesi. Samples who met the criteria and used in this study are 83 primary school children. They were recruited randomly from primary school. Participants consist of 48 Girls and 35 Boys were brought in and examined for pediculus capitis infestation. Mothers' educational level were gained from school database. Results and Discussion: The prevalence of pediculosis capitis was $68.7 \%$ (57 students), in which 39 out of 48 girls had pediculosis capitis $(81 \%)$ in contrast to the $18(51 \%)$ out of 35 pediculosis capitis in boys. Statistically, using Chi Squares tests, the prevalence of pediculosis capitis is associated with gender (p 0.04). Meaning that Girls, like many publications sugested, still have higher presentation for head louse infestation than boys. Several factors are suggested to contribute for this prevalence including the length of girls' hair and using the same combs, bandana, towel, and other stuff together. Regarding mothers' education level, there is no significant differences have been found. The highest percentage of infected children $(45.8 \%)$ have mother who graduated from senior high school. Only $2.4 \%$ children with lice have mother with elementary level of education, compared to $7.2 \%$ infected children with Bachelor mother. Louse infestation occurred in all children regardless their parent's education background. In Conclusion: Prevalence of pediculosis capitis is still high amongst school children, in which girls has a higher infestation of pediculus capitis than boys. Parents education background seems to have no correlation with the prevalence. Since the prevalence of pediculosis capitis is still high all over the world including the area in which this study took place, many factors that contribute to this still needs to be identified and explored in further studies to provide a strong foundation to aid future effort in mitigating this problem.

Keywords: pediculosis capitis, sleeping disturbances, Parents, education level.

Copyright $\odot 2020$ The Author(s): This is an open-access article distributed under the terms of the Creative Commons Attribution 4.0 International License (CC BY-NC 4.0) which permits unrestricted use, distribution, and reproduction in any medium for non-commercial use provided the original author and source are credited.

\section{INTRODUCTION}

Infestation of pediculus capitis has occurred since a long time ago, but until now, both in developed and developing countries, pediculosis has not been eradicated completely and continues to effect community members, especially children as the main hosts of this parasite $[1,2]$. The prevalence rates in each country vary, as well as each region or state [3]. There are many countries that have reported the incidence of pediculosis, where these studies were conducted in both developed and developing countries on a national and regional (regional) scale. Some results have reported a prevalence of pediculosis below 10 percent, namely in England (2.4\%) [3], South Korea 5,8\% [4], Belgia 8,9\% and Malaysia $9.3 \%$ [5]. Prevalences of more than $10 \%$ to $50 \%$ were reported in Saudi Arabia 12\% [3], Thailand 12,6 to $29,7 \%$, Australia $13 \%$, Turki Kayseri 
$13,3 \%$, India 16,59\% [6], Kenya 17,1\%, DI Khan 20\%, Karachi $25 \%$, Peshavar $45 \%$ [3], Brazil 28 to $35 \%$, and West Sumatra 51,92\% [5]. Furthermore, there are also studies that reported more than $50 \%$ of subjects infested with human pediculus capitis those were the study done in Egypt 58.9\%, Argentina 81.9\% [5] Ukraine 52\% [6], Jogjakarta (Indonesia) 71,3\% 9 [7], Pakistan 77,4\% [3], Turki 69,5\%, Lybia 78\% [8] and Jombang (Indonesia) $100 \%$ [9]. The studied population varied from primary school children, boarders, slum dwellers and other communities. The general description that can be obtained is that the prevalence of pediculosis humanus capitis in developed countries is lower than developing countries. The reported prevalence rates need to be further reviewed to see the population studies and the methods used.

In Indonesia, the prevalence reported from one researcher to another in the same area still varies. Data collection, sample, population examined also varies. Many studies were conducted with samples from existing dormitories, with a high enough prevalence and even up to 100 percent [9]. In North Sulawesi, a study was conducted on 5 existing orphanages and obtained a prevalence rate of $15 \%$ [10]. However, the most recent research, which was conducted on children in several Sunday schools and elementary school children, shows a prevalence that is so striking, namely above $70-85$ percent [11]. This shows that there are still many children who are infested with head lice.

Pediculus capitis infestation is known as pediculosis capitis, affecting all strata of social life [12, 13], either in developed or developing countries [14, 15]. The management of pediculosis capitis in the United States is reported to be up to 1 billion dollars, including drug and other costs directly related to the infestation of pediculosis capitis [16, 13, 17]. Even though it is classified as a non-life threatening disease, pediculosis capitis is a public health problem in the world, because the disturbance caused by this mite could afflict further socio economic damages for the patients [14]. Some of the psychological problems experienced by people with pediculosis capitis, namely feeling ashamed, inferior, isolated, fearful, and even frustrated due to the stigma by the society that implies that patients with pediculosis capitis are linked to having poor hygiene, to be below poverty line, and neglected children [8]. The clinical symptom that are presented depends on the severity of the lice infestation and the treatment performed. In children with malnutrition, head lice infestations worsen the nutritional status of these children and can cause anemia [8].

This study will examine the prevalence of pediculosis capitis in elementary school children in Kawiley village and analyze the relationship between gender and parental education.

\section{MeTHODS}

This study used a survey method with a crosssectional approach to elementary school children in Kawiley village. Permission to examine children is obtained from the teacher or directly from the parents. Children who met the inclusion criteria were not treated for head lice for 2 weeks and were willing to become respondents, completing the respondent characteristics data. The child was examined by manual method, namely the hair was combed with a fine comb and louse were observed on a white cloth, if necessary the examination was followed by direct inspection of the child's head and hair, especially the back of the ear. The results of the examination are recorded and the data is processed further.

\section{RESULTS}

This research was conducted in Kawiley village North Sulawesi, Indonesia. This village is approximately 1458 hectares, has 4 elementary schools, with 203 students, and the primary school with the most students is SD GMIM Kyrios Kawiley. Of the total population of 115 children at SD GMIM Kawiley, 83 children met the inclusion criteria and were recruited to be included in this study, consisting of 48 girls and 35 boys. There were 39 Girls and Boys students with head lice infestations (81.3\%) and 18 students (51.4\%), respectively. Comparing the gender of kids with head lice infestation using Chi Square was shown to be statistically significant. This gender based head lice infestation can be seen in the following table.

Table-1: Infestations of pediculosis capitis by gender
\begin{tabular}{|l|l|l|l|}
\hline \multirow{2}{*}{ Gender } & Pediculosis Capitis & Statistics \\
\cline { 2 - 3 } & No & Yes & \\
\hline Girls & $9(18.8 \%)$ & $39(81.3 \%)$ & .004 \\
\hline Boys & $17(48.6 \%)$ & $18(51.4 \%)$ & \\
\hline Total & $26(31.3 \%)$ & $57(68.7 \%)$ & \\
\hline
\end{tabular}

In society, girls are stated to have more close relationship each other compared to boys' counterparts. They easily use their stuff together such as combs, bandana, towel and even sleep over frequently. This close contact is potentially increasing the prevalence of pediculosis capitis among girls.

Parental education in this research is specifically focused on maternal education, because mothers are figures who spend more time caring for their children. Children whose mothers' highest level of education was senior high school was shown to have the highest head lice infestations a total of 38 children $(65.5 \%)$. At the lowest level of mother's education, namely elementary school, only $2(2.4 \%)$ children were infested with head lice, while there were 6 children with head lice whose mothers has a bachelor's degree (Table2). The analysis showed no significant association on the prevalence of pediculosis capitis and the mother's level of education. 
Table-2: Infestations of pediculosis capitis and mothers level of education

\begin{tabular}{|l|l|l|l|}
\hline \multirow{2}{*}{$\begin{array}{l}\text { Mothers } \\
\text { Education }\end{array}$} & \multicolumn{2}{|l|}{ Pediculosis Capitis } & \multirow{2}{*}{ Statistics } \\
\cline { 2 - 3 } & No & Yes & \\
\hline Elementary & 0 & $2(2.4 \%)$ & .547 \\
\hline $\begin{array}{l}\text { Junior High } \\
\text { School }\end{array}$ & $5(6 \%)$ & $11(13.3 \%)$ & \\
\hline $\begin{array}{l}\text { Senior High } \\
\text { School }\end{array}$ & $\begin{array}{l}20 \\
(24.1 \%)\end{array}$ & $\begin{array}{l}38 \\
(45.8 \%)\end{array}$ & \\
\hline Bachelor & $1(1.2 \%)$ & $6(7.2 \%)$ & \\
\hline Total & $\begin{array}{l}26 \\
(31.3 \%)\end{array}$ & $\begin{array}{l}57 \\
(68.7 \%)\end{array}$ & \\
& \multicolumn{2}{|l}{} \\
\hline
\end{tabular}

\section{DISCUSSION}

Pediculosis humanus capitis is known to be a parasitic disease accruing mostly in children, that is why the research conducted by most of the respondents was elementary school children [18-22]. Head lice infestation often does not receive sufficient attention from stakeholders such as the government, society and even those affected by this, because this is often perceived as mere discomfort as appose to it being a health concern that could effect the quality of life. In developing countries researches and management of pediculosis capitis are limited and scarce [23], this is mostly due to the fact that the allocation on healthcare funds are used to focus more on other demanding healthcare issues. Sweileh reports that pediculosis capitis is one of the neglected epidermal parasitic skin diseases. Sweileh [24], however on a socio-economics perspective it has a substantial influence on the population [25].

The prevalence of pediculosis capitis in this study was $68.7 \%$ of children in primary schools infested with head lice. This prevalence is quite high compared to studies reported recently in several places, $2.01 \%$ in the European Union [26], 12.2\% in Riyadh, Saudi Arabia [21], 10\% in Barat Daya Iran [25] and 44\% in Batambang, Cambodia [27]. Respondents from the researches mentioned previouslty were generally elementary school children in urban areas, where as this research was conducted in rural areas. (Figure 1 Location of Kawiley village).

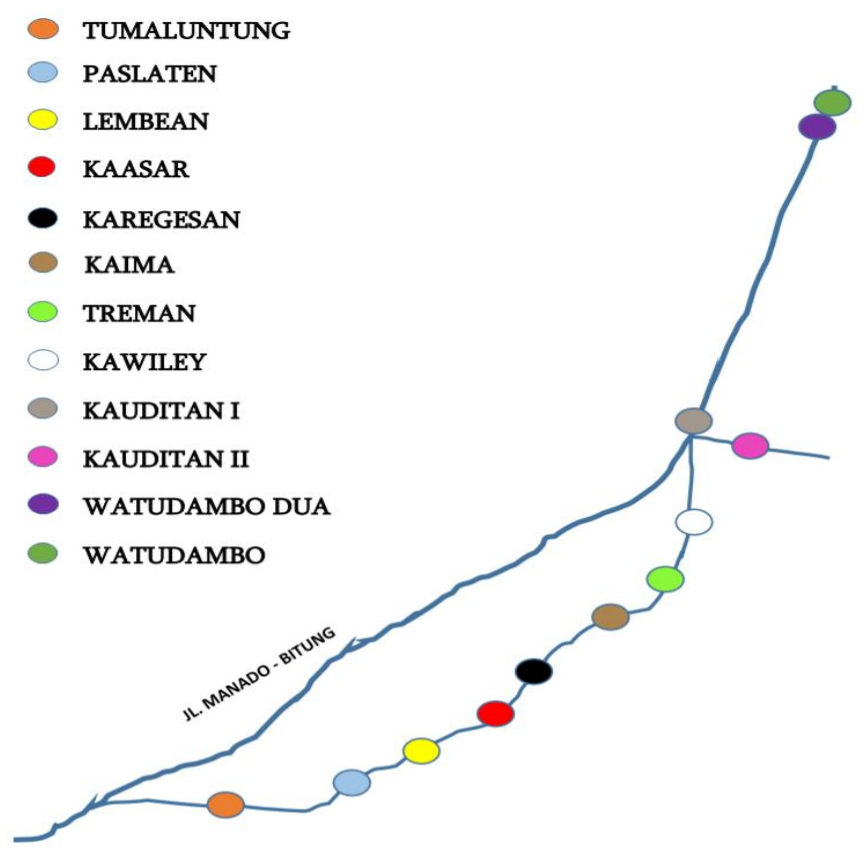

Fig-1: Kawiley Vilage (Rignolda Djamaluddin)

In rural areas, pediculosis capitis was reported to be higher by a number of earlier studies [26]. Megrin [21] had point out that area of residence contributes significantly to the rate of head lice infestation in children $(19,2 \%, p<0.001)$. A study conducted at Sabang city, Province of Aceh Indonesia, reported that urban account for $26,6 \%$ prevalence of pediculosis capitis compared to $27.1 \%$ of children with infestation of pediculus capitis in rural area [28]. Residing neighborhood has been found as a risk factor in the infestation of pediculus capitis. Twenty two point forty four present of primary school children living in rural area of Kuzestan, Iran had pediculosis capitis, while only $6.58 \%$ their counterpart in urban area had infestation of this lice [25]. The risk of head lice infestation increases to 2.3 times in the rural area [29]. These reports are in agreement with the high percentage of pediculosis capitis found in the current study.

Gender plays an important role as a risk factor in the occurrence of pediculosis capitis. A great majority of studies reported comparable findings regarding gender differences and its relation to pediculus capitis prevalence among children. In this study, girls were much more likely to have head lice infestations than boys which was only $19 \%$. Liao et al found the rate of pediculosis capitis infestation in girls among 323 children were 143 (44.3\%), and girls were 
significantly higher than boys [27]. In the Eastern region of the European Union, lice infestation also showed higher among girls $(59,52 \%)$ compared to boys $(40.48 \%)$ [26]. Girls seem to have closer contact with each other and usually share their personal belongings such as combs, hair accessories, dan bathing appliances such as towel and soap. Moreover, in this village, bathing in a communal bathing areas are common among children with low socioeconomic status, due to lack of water resources in their own house. Therefore the likelihood of lice transmitting is still high amongst children, girls in particular.

The educational levels of mothers who have the most children with pediculosis capitis were mostly at the senior high school level. An interesting picture is seen in mothers with graduate education (a bachelor degree) having children $85.7 \%$ (6 children) children with pediculosis capitis compared to the $14.3 \%$ (1 child), who not infested. Statistically, the educational level of mothers has no effect on the infestation rate. Maternal education was also found to be unrelated to head lice infestations in several studies $[30,31]$. Other studies however discovered different findings. Krisnawati [7] and a few other studies found education level of either the mother or the father to be a significant factor in the prevalence of pediculosis capitis $[18,29,19,7,21,32]$. In a conventional society like that Kawiley village mothers still takes upon the domestic role as the primary caregiver for her children. In this study, mothers who only had passed elementary schools' education did not have more children with pediculosis capitis in comparison to the groups of mothers with higher level of education. Even the group of mothers with the highest level of education (bachelor) still had children with pediculosis capitis. A number of other associated factors could play a role in this. Busy working schedule for example, could be affiliated with the inability to provide the necessary attention needed to detect a head louse infestation, the number of children in a family is another example of factors that could limit the capability of parents, in this case mothers to further mitigate head louse problem. These other associated factors and the different findings in the studies mentioned previously, leaves more room to perform further study to investigate these incidence.

\section{CONCLUSION}

Pediculus humanus capitis still affects school children in Kawiley with prevalence rate more than half percent of respondents. Girls are more likely to suffer with this parasite compared to boys. Parent's educational background do not seem to contribute significantly and affect to the prevalence rate.

Conflict of Interest: Researchers have no conflict of interest in this particular study.

\section{REFERENCES}

1. Burkhart CG, Burkhart CN. Safety and efficacy of pediculicides for head lice. Expert opinion on drug safety. 2006 Jan 1;5(1):169-79.

2. Ko C, Elston DM. Pediculosis. Tropical Dermatology: Second Edition, 2016; 387-392. https://doi.org/10.1016/B978-0-323-296342.00030-4

3. Afzal S, Fatima S, Shahzad P, Rani A, Bashir A, Hasr A. Prevalence of Pediculus Humanus Capitis Infestation and Socio-economic Status in School Children; a Review. Global Scientific Journals, 2018; 6(11), 180-187. www.globalscientificjournal.com

4. Oh JM, Lee IY, Lee WJ, Seo M, Park SA, Lee SH, Seo JH, Yong TS, Park SJ, Shin MH, Pai KS. Prevalence of pediculosis capitis among Korean children. Parasitology research. 2010 Nov 1;107(6):1415-9.

5. Salim S, Alatas S, Linuwih S. Hubungan Tingkat Pengetahuan Mengenai Pedikulosis Kapitis dengan Karakteristik Demografi Santri Pesantren X, Jakarta Timur. 2013; 1(1).

6. Yunida S, Rachmawati K. Faktor-Faktor Yang Berhubungan Dengan Kejadian Pediculosis Capitis Di Smp Darul Hijrah Putri Martapura: Case Control Study. 2015; 124-132.

7. Kristiawati K, Diyan RP, Setyowati R. Factors affecting Pediculosis capitis prevention at Islamic boarding school in Indonesia. Advances in Health Sciences Research, 2017; 3(Inc), 21-24. https://doi.org/10.2991/inc-17.2017.11

8. Sari D. Dampak Infestasasi Pedikulosis Kapitis Terhadap Anak Usia Sekolah. Jurnal Majority. 2016 Dec 1;5(5):69-74.

9. Wijayati F. Hubungan Antara Perilaku Sehat Dengan Angka Kejadian Pedikulosis Kapitis Pada Santriwati Pondok Pesantren Darul 'Ulum Jombang. 2007.

10. Rumampuk MV. Peranan kebersihan kulit kepala dan rambut dalam penanggulangan epidemiologi. 2012.

11. Massie MA, Wahongan GJP, Pijoh V. Prevalensi Infestasi Pediculus humanus capitis pada Anak Sekolah Dasar di Kecamatan Langowan Timur. 2020; 1(28), 24-30.

12. Bradley NB, Leslie VS. Pediculosis Humanis (Lice, Capitis, Pubis). StatPearls Publishing LLC. 2020.

https://www.ncbi.nlm.nih.gov/books/NBK470343/

13. Eisenhower C, Farrington EA. Advancements in the Treatment of Head Lice in Pediatrics. Journal of Pediatric Health Care, 2012; 26(6), 451-461. https://doi.org/10.1016/j.pedhc.2012.05.004

14. Leung AKC, Fong JHS, Pinto-Rojas A. Pediculosis capitis. Journal of Pediatric Health Care. 2005.

https://doi.org/10.1016/j.pedhc.2005.07.002

15. Nutanson I, Steen CJ, Schwartz RA, Janniger CK. Pediculus humanus capitis: An update. In Acta 
Dermatovenerologica Alpina, Pannonica et Adriatica. 2008.

16. Devore CD, Schutze GE. Head Lice. Pediatrics, 2015; 135(5), e1355-e1365. https://doi.org/10.1542/peds.2015-0746

17. Hansen RC. Economic Considerations Associated with Pediculus humanus capitis Infestation. Clinical Pediatrics, 2004; 43(August), 523-527.

18. Al-Maktari. Head louse infestations in Yemen: prevalence and risk factors determination among primary schoolchildren, Al-Mahweet Governorate, Yemen. J Egypt Soc Parasitol. 2008 Dec; 38(3): 741-748.

19. Bosely HA, El-Alfy NM. Head lice infestations (Anoplura: Pediculidae) in Saudi and non-Saudi school-aged children. Journal of the Egyptian Society of Parasitology. 2011 Apr;41(1):131-40.

20. Louni M, Amanzougaghene N, Mana N, Fenollar F, Raoult D, Bitam I, Mediannikov O. Detection of bacterial pathogens in clade e head lice collected from Niger's refugees in Algeria. Parasites and Vectors, 2018; 11(1). https://doi.org/10.1186/s13071-018-2930-5.

21. AL-Megrin WA. Assessment of the prevalence of pediculosis capitis among primary school girls in Riyadh, Saudi Arabia. Research Journal of Environmental Sciences. 2015 May 20;9(4):193199. https://doi.org/10.3923/rjes.2015.193.199

22. Özkan Ö, Hamzaoğlu O, Yavuz M. Türkiye' de Pedikulozis Kapitis Prevalansı ve Yönetimi: Sistematik Derleme The Prevalence and Management of Pediculosis Capitis in Turkey: A Systematic Review. 2012; 135-146. https://doi.org/10.5152/tpd.2015.3628

23. Speare R, Harrington H, Canyon D, Massey PD. A systematic literature review of pediculosis due to head lice in the Pacific Island Countries and Territories: What country specific research on head lice is needed? BMC Dermatology, 2014; 14(1), 1-6. https://doi.org/10.1186/1471-5945-1411

24. Sweileh WM. Global output of research on epidermal parasitic skin diseases from 1967 to 2017. Infectious Diseases of Poverty, 2018; 7(1), 1-10. https://doi.org/10.1186/s40249-018-0456-x

25. Nejati J, Keyhani A, Tavakoli KA, Mahmoudvand H, Saghafipour A, Khoraminasab M, Tavakoli OR, Mousavi SM. Prevalence and risk factors of pediculosis in primary school children in south west of Iran. Iranian Journal of Public Health, 2018; 47(12), 1923-1929.

26. Bartosik K, Buczek A, Zając Z, Kulisz J. Head pediculosis in schoolchildren in the eastern region of the European Union. Annals of Agricultural and Environmental Medicine, 2015; 22(4), 599-603. https://doi.org/10.5604/12321966.1185760

27. Liao CW, Cheng, PC, Chuang TW, Chiu KC, Chiang IC, Kuo JH, Tu YH, Fan YM, Jiang HT, Fan CK. Prevalence of Pediculus capitis in schoolchildren in Battambang, Cambodia. Journal of Microbiology, Immunology and Infection, 2019; 52(4), 585-591. https://doi.org/10.1016/j.jmii.2017.09.003

28. Yuni N. Prevalensi Infestasi Kutu Kepala (Pediculus Humanus Capitis) Dan Faktor Risiko Penularannya Pada Anak Sekolah Dasar Di Kota Sabang Provinsi Aceh. 2016.

29. Gulgun M, Balci E, Karaoğlu A, Babacan O, Türker T. Pediculosis capitis: Prevalence and its associated factors in primary school children living in rural and urban areas in Kayseri, Turkey. Central European Journal of Public Health, 2013; 21(2), $104-108$ https://doi.org/10.21101/cejph.a3750

30. Doroodgar A, Sadr F, Doroodgar M, Doroodgar M, Sayyah M. Examining the prevalence rate of Pediculus capitis infestation according to sex and social factors in primary school children. Asian Pacific Journal of Tropical Disease, 2014; 4(1), $25-29$. 1808(14)60308-X

31. Joyce A, Yit, L, Murhandarwati EEH, Rahmah S. Head Lice Infestation and Its Relationship with Hygiene and Knowledge among Urban School Children in Yogyakarta. Head Lice Infestation and Its Relationship with Hygiene and Knowledge among Urban School Children in Yogyakarta, 2014; 1(1), 35-41. https://doi.org/10.22146/tmj.4565

32. Vahabi A, Shemshad K, Sayyadi M, Biglarian A, Vahabi B, Sayyad S, Shemshad M, Rafinejad J. Prevalence and risk factors of Pediculus (humanus) capitis (Anoplura: Pediculidae), in primary schools in Sanandaj city, Kurdistan province, Iran. Tropical Biomedicine, 2012; 29(2), 207-211. 